\title{
Strategic Analysis \& Countermeasure study on Environmental Logistics
}

\author{
Zhiguo Fan ${ }^{a}$, Mengkun $\mathrm{Ma}^{\mathrm{b}}$ \\ School of Management, Tianjin University of Technology, Tianjin 30084, China. \\ a1102760520@qq.com, bmamengkun2010@163.com
}

\begin{abstract}
Human material civilization and spiritual civilization are improved along with the continuous development and progress of the social economy. However, resources we live on are decreasing while industrial waste, car exhaust, and other hazardous materials are increasing, which are threatening the ecological environment and our earth. Therefore, as a sustainable development strategy, the environmental logistics is also a difficult task, which has gradually become one of the important tasks of enterprises, and also one of social issues. Environmental logistics has been carrying out the strategy of sustainable development, which plays an irreplaceable role in the development of both the society and the enterprise.
\end{abstract}

Keywords: Environmental logistics; Sustainable development; Ecological environment.

\section{Introduction}

Today, environmental protection and resource conservation have become the most important mission of 21 st century as the society is facing serious environmental pollution and resources waste. With the continuous exploration by people, the environmental logistics has come into the public, and many scholars and experts believe that the development trend of environmental logistics is what the people want. For example, the American management schools believe that traditional logistics is a process of delivery or effective work, while the environmental logistics pay more attention to environmental protection and resource conservation so that the entire logistics process losses is greatly reduced. To enterprises, the development of environmental logistics is helpful to improve the economic efficiency of enterprises, establish a good corporate image, and be easy to get the recognition and support of the government and society, which can lay a good foundation for long-term development. This paper aims to introduce the concept of environmental logistics to provide new reference for the majority of enterprises in energy saving on the road. Although many people know the logistics and talk about, few people know how many benefits it can provide. This paper will adopt quantitative method to demonstrate the feasibility and reasonableness of environmental logistics for enterprises.

\section{Definition and Essential Features of Environmental Logistics}

The so-called environmental logistics is the process by adopting advanced logistics technology to make logistics activities (purchasing, production, transportation, storage, and packaging, product sales and recycling) under environmental control and management to reduce pollution and resource consumption. In addition to the normal forward logistics, environmental logistics also contains the reverse logistics. Its main body involves enterprises, consumers and some related government organizations, which should coordinate with each other for reasonable and efficient management [1].

Although there was different views on environmental logistics at home and abroad, the views on the nature and connotation are basically same with details as below.

Sustainable development as the ultimate goal of environmental logistics. The environmental logistics is keen on reducing waste of resources and protecting the environment, so it is conformed to the trend of social development. Developing the environmental logistics is to reduce waste emissions and promote recycling of resources. The minimum consumption of resources will strengthen the protection of environment to a certain extent [2].

Activities of environmental logistics covering the entire production process. The environmental logistics go through the entire process of products, which damage and threat to the ecology during the 
purchase of raw materials to production to sales and to final abandoned process. Thus, the development environmental logistics should be considered throughout the entire product life cycle.

Public, government and all elements of the supply chain involving in environmental logistics. The environmental logistics is aimed at foundational employees and some staff of some businesses and enterprises, which has great influence and strong enforceability.

\section{Current Status of Environmental Logistics}

China is at a stage of rapid economic development with increasingly fierce market competition and many companies springing up [3]. On the one hand, companies can improve competition ability through the development of environmental logistics, and thus play a role in maintaining economic growth. On the other hand, serious shortage of natural resources lead to the slow development of environmental logistics. Due to relatively inadequate technologies in our country, it is extensive growth at the initial stages of economic development, which results in serious damage to the natural environment and a tremendous waste of resources. Nowadays, available renewable resources is less and less in our country. The destruction of the natural environment is also negatively affecting major companies. At the same time, because of the continuous growth of the population and the people's growing material and cultural needs, it brings great pressure to the development of economy and the use of natural resources, environmental logistics to carry out precisely this background came into being [4]. At the present, there also exist some problems among enterprises in our country on environmental logistics: lagging concept, lagging policy, lagging technology. Those seriously restricts the development of our environmental logistics industry, so we should continue to reform and innovate breakthrough restrictions and form our unique features.

\section{Case Analysis on Environmental Logistics}

As environmental logistics is applicable to many types of enterprises, this paper just takes logistics companies as a research object to understand typical advantages after implementation of the environmental logistics in packaging and electronic invoicing.

\section{1 Packaging}

For a logistics enterprise, the packaging is the most important as the packaging is an important channel to achieve low-carbon economy. At present, mainstream packaging materials on the market mainly includes packaging paper, biodegradable plastics, composite packaging materials, aluminum foil and spray aluminum packaging, renewable materials packaging and so on.

(1) Comprehensive analysis of the packaging material.

To determine the best packaging materials for logistics companies, we designed a table (Table 1) to calculate the value of different packaging materials.

Table 1 Index score of mainstream packaging materials

\begin{tabular}{ccccccc}
\hline Name & $\begin{array}{c}\text { Environmental } \\
\text { protection } \\
(0.2)\end{array}$ & $\begin{array}{c}\text { Economic } \\
(0.3)\end{array}$ & $\begin{array}{c}\text { Automatic } \\
\text { sorting } \\
(0.15)\end{array}$ & $\begin{array}{c}\text { Transport } \\
(0.15)\end{array}$ & $\begin{array}{c}\text { Security } \\
(0.15)\end{array}$ & $\begin{array}{c}\text { Commercial } \\
(0.05)\end{array}$ \\
\hline Packaging Paper & 6 & 6 & 4 & 4 & 4 & 4 \\
Biodegradable plastics & 4 & 4 & 6 & 6 & 6 & 4 \\
Composite packaging materials & 4 & 6 & 6 & 6 & 6 & 4 \\
Aluminum foil and spray & 4 & 4 & 6 & 6 & 6 & 6 \\
aluminum packaging & 6 & 2 & 4 & 4 & 4 & 4 \\
Renewable materials packaging & 6 & & & 6 & & 6 \\
\hline
\end{tabular}

The scoring method is adopted to analyze the value of the package: 6 represents the high-value, 4 represents the medium value and 2 represents the lower value. In addition, we give different weights to different indicators: Environmental protection (0.2), Economic (0.3), Automatic sorting (0.15), Transport (0.15), Security (0.15), Commercial (0.05). 
Composite score:

Packaging paper $=6 * 0.2+6 * 0.3+4 * 0.15+4 * 0.15+4 * 0.15+4 * 0.05=5$

Biodegradable plastics $=4 * 0.2+4 * 0.3+6 * 0.15+6 * 0.15+6 * 0.15+4 * 0.05=4.9$

Composite packaging materials $=4 * 0.2+6 * 0.3+6 * 0.15+6 * 0.15+6 * 0.15+4 * 0.05=5.5$

Aluminum foil and spray aluminum packaging $=4 * 0.2+4 * 0.3+6 * 0.15+6 * 0.15+6 * 0.15+6 * 0.05=5$

Renewable materials packaging $=6 * 0.2+2 * 0.3+4 * 0.15+4 * 0.15+4 * 0.15+4 * 0.05=3.8$

By calculation, we can conclude that composite packaging materials is the most suitable packaging materials for logistics companies.

(2) Composite packaging material return on investment analysis with details in Table 2.

Table 2 Analysis on return on investment of composite packaging materials

\begin{tabular}{|c|c|c|c|c|}
\hline $\mathbf{C}^{\text {Type }}$ & \multicolumn{2}{|c|}{ Cost analysis } & \multicolumn{2}{|c|}{ Recovery analysis } \\
\hline \multirow{2}{*}{$\begin{array}{c}\text { Existing packaging } \\
\text { materials (packaging paper } \\
\text { packaging plastic, etc.) }\end{array}$} & $\begin{array}{l}\text { Product Cost - } \\
\text { Cost recovery }\end{array}$ & RMB(250-0)thousand & \begin{tabular}{|c|} 
Social \\
value(environmental \\
value)
\end{tabular} & $\begin{array}{l}\text { RMB } 20 \\
\text { thousand }\end{array}$ \\
\hline & Total amount & RMB 250 thousand & Recovery value & $\begin{array}{l}\text { RMB } 30 \\
\text { thousand }\end{array}$ \\
\hline \multirow{2}{*}{$\begin{array}{c}\text { composite packaging } \\
\text { materials }\end{array}$} & $\begin{array}{l}\text { Product Cost - } \\
\text { Cost recovery }\end{array}$ & RMB(250-50)thousand & $\begin{array}{c}\text { Social } \\
\text { value(environmental } \\
\text { value) }\end{array}$ & $\begin{array}{l}\text { RMB } 50 \\
\text { thousand }\end{array}$ \\
\hline & Total amount & RMB 200 thousand & Recovery value & $\begin{array}{l}\text { RMB 50 } \\
\text { thousand }\end{array}$ \\
\hline
\end{tabular}

Analysis on ROI of packaging recycling with details in Table 3.

Table 3 Analysis on ROI of packaging recycling

\begin{tabular}{cc|cc}
\hline \multicolumn{2}{c|}{ Cost analysis } & \multicolumn{2}{c}{ Recycling analysis } \\
\hline Standardization input cost & RMB 250 thousand & Save packaging cost & RMB 150 thousand \\
Delivery staff training cost & RMB 30 thousand & No-load cost & RMB 50 thousand \\
$\begin{array}{c}\text { Salaries of delivery staff increased } \\
\text { cost }\end{array}$ & RMB 60 thousand & Sorting cost & RMB 350 thousand \\
Total & RMB 340 thousand & Total & RMB 550 thousand \\
\hline
\end{tabular}

According to Table 3, we find that packaging recycling can save a lot of costs for the logistics enterprise.

\section{2 Electronic Invoicing}

In the field of electronic invoicing, we need to know its cost structure.

(1) The cost of saving paper

The cost of ordinary paper bills: Average per A4 paper requires at least about RMB 0.04. If the logistics company daily orders is about 20000 with 5 pages per order: shipper page, delivery page, finance page, retaining page etc, the daily saving paper cost is $0.04 * 5 * 20000=\mathrm{RMB} 4000$, the annual savings of paper costs about $365 * 4000=$ RMB 1460 thousand.

(2) The cost of Electronic bill of lading

If the logistics company transport 30 tons of cargo by air, they can save nearly half an hour each time. If they increase 4 flights to transport 120 tons of goods every day, then 43800 tons of cargo can be increased each year, and Logistics companies in the aviation sector will be increased $10 \%$ profits about RMB 1200 thousand each year.

(3) Purchase cost of equipment

The cost of general self-service machine equipment of the electronic invoicing system is about RMB 80000 each unit, so the increase cost of 100 machines will be $80000 * 100=$ RMB 8000 thousand. The RFID radio frequency technology equipment priced at RMB 500, so the increase of 500 machines is RMB 250 thousand. A Mobile Internet Device (MID) is RMB 5500, so the increase of 200 machines is $5500 * 200=\mathrm{RMB} 1100$ thousand. 
The total cost of above equipment is about $8000000+250000+1100000=\mathrm{RMB} 9350000$

(4) Total cost analysis

We use the static payback period method to calculate with details in Table 4.

Table 4 Analysis of electronic waybill return on investment

\begin{tabular}{|c|c|c|c|}
\hline Ineome from investment & \multicolumn{2}{|c|}{ Receipts } & Investment \\
\cline { 2 - 4 } value & The cost of paper & Time costs & Equipment costs \\
\hline Cost & RMB 1460 thousand & $\begin{array}{c}\text { RMB 1200 } \\
\text { thousand }\end{array}$ & RMB 9350 thousand \\
\hline Total & \multicolumn{2}{|c|}{ RMB 2660 thousand } & RMB 9350 thousand \\
\hline
\end{tabular}

(Note: Analysis of annual cost)

Investment payoff period: $\mathrm{p}=3.5$ this means that we can use four years to recover all investment costs. Obviously, this program has great feasibility so it is worth to implement.

\section{Summary}

Now, the society is facing the increasingly competition, so it is not just the competition between enterprises. It gradually shifts to the direction of economic benefits and social responsibility. This transformation makes each large enterprise explore the new way of development, while environmental logistics is both economical and friendly environmentally [5]. In this paper, it proves that the development of environmental logistics is an economic and social effective measure through the environmental logistics meanings and essence describing, the specific economic interests balancing in the enterprise. The environmental logistics is a rare development direction. This paper adopts quantitative method to prove the great benefits that the development of environmental logistics can bring to enterprises. We are confident that the environmental logistics will become another new growth point of economic development, wish it be able to get enough attentions from enterprises, and also wishes China's environmental logistics develop their own special features to compare with international ones.

\section{References}

[1] Paul Murphy, Richard. Green Logistics Strategies: An Analysis of Usage Patterns [J]. Transportation Journal winter 2000, (3):5-6.

[2] Liru Zhang. Development Tactics of Environmental Logistics [J]. Hebei Jiaotong Science And Technology, 2008, 5(2):18-19

[3] Yifan Li, Na Li. Some Considerations about Low-Carbon Logistics [J]. Logistics Sci-Tech, 2011, (1): $51-53$

[4] Fang Qin. The study of the current situation of environmental logistics in our country [J]. Scientific Management, 2011, (2): 9-10

[5] XuMing ShangGuan. Environmental Logistics Optimization Model [J]. CHUANGXINKEJI, 2010, 6(12): 22-23 